\title{
What doctors should know about the Trans-Pacific Partnership Agreement
}

\author{
How this new breed of trade agreement could affect public health and access \\ to medicines
}

$\mathrm{M}$ acroeconomic policy decisions can seem far removed from day-to-day medical practice; however, these high-level policy decisions about trade and economic policy have far-reaching consequences and can undermine effective health policy and practice.

\section{The Trans-Pacific Partnership Agreement}

The Trans-Pacific Partnership Agreement (TPPA), currently under negotiation, represents a new breed of trade agreement. ${ }^{1}$ It will include the traditional focus areas, like removing import taxes and enabling foreign companies to provide services in Australia; and it is believed it will provide new protections for investors and intellectual property. The TPPA is aimed at changing policy making within countries and harmonising domestic policy requirements affecting trade and investment across the countries involved. ${ }^{2}$

\section{"independent assessment of the implications for public health is severely limited by lack of transparency in the negotiations"}

As a new-style agreement, the TPPA has greater potential to affect domestic health policy and, ultimately, the quality of health services and public health. ${ }^{3}$ For example, leaked documents show that an investor-state dispute settlement mechanism is being negotiated for the TPPA. This enables foreign investors - including companies that manufacture, market and distribute health-damaging products - to directly seek compensation from governments for policies that negatively affect them. A similar mechanism in another treaty enabled Philip Morris Asia to sue the Australian Government over plain tobacco packaging. ${ }^{4}$ Similarly, moves to harmonise policies within signatory countries that affect traded goods can result in a move to the lowest common denominator and can limit public health protections related to medicines, tobacco, alcohol and food. for Health Policy, Sydney, NSW. 2 La Trobe University, Melbourne, VIC. 3 Regulatory Institutions Network,

Canberra, ACT.

annemarie.thow@ sydney.edu.au

doi: 10.5694/mja14.01714

Online first 09/02/15 lack of transparency in the negotiations (the agreement will not be made public until after it is signed). ${ }^{6}$

\section{Main areas of concern for doctors}

One of the key concerns for doctors is access to medicines. Intellectual property rules proposed for the TPPA, if adopted, are likely to prolong monopolies over new medicines and delay the availability of cheaper generics. ${ }^{47}$ Resulting cost blowouts to the Pharmaceutical Benefits Scheme (PBS) would play out for patients in higher copayments and reduced access to expensive new treatments, with disadvantaged patients bearing much of the burden. ${ }^{8}$ Changes to PBS processes also proposed for the TPPA could compound these problems by preventing effective price regulation and giving the pharmaceutical industry more say in PBS decision making., In addition, pharmaceutical companies may be able to use the investor-state dispute settlement mechanism to sue, or threaten to sue, governments over their pharmaceutical policies. Pharmaceutical company Eli Lilly and Company is currently using an investor-state dispute settlement mechanism to sue the Canadian Government for invalidating patents for two drugs that were found not to deliver the promised benefits. ${ }^{8}$

The TPPA could also make the shared task of tackling chronic non-communicable diseases such as diabetes and heart disease more difficult. Prevention through supportive environments is an essential corollary to general practitioner-based primary prevention. Nevertheless, the rules of these new trade agreements that are focused on domestic policy can reduce the options available to government for regulating products associated with non-communicable disease prevention, namely tobacco, alcohol and food. ${ }^{9}$ For example, proposed rules on transparency and regulatory coherence in the TPPA would enshrine the right of industry (both local and international) to contribute to national nutrition policy making. This works against public health efforts to reduce the influence of vested interests on policy design and implementation. Without strong population-based prevention, such as clear labelling of health risks, limitations on advertising and price incentives to reduce consumption (all strongly opposed by industry), the burden falling on GP-based primary prevention will continue to grow.

Doctors should also be concerned about the implications of the TPPA for health services. The TPPA is expected to include rules to ensure private companies can compete on an equal footing with publicly funded or provided services..$^{10}$ Owing to limited public information, it is difficult 
to establish how current and future public health services will be affected. But if parts of the health system are privatised (such as Medicare claims processing and primary health care networks), this may not be reversible under the TPPA, regardless of any subsequent evidence of detrimental effects of such privatisation.

\section{What doctors can do}

The Australian Medical Association and the Public Health Association of Australia have raised concerns about the potential impact of the TPPA on public health and access to medicines. ${ }^{6,11}$ Such input is essential for awareness among policymakers of the cross-sectoral implications of trade policy decisions. Doctors can help to protect public health by highlighting the effects of proposed provisions on patients, opposing health-damaging provisions, arguing for the agreement to be worded in ways that protect public health and seeking greater transparency in the TPPA negotiations.

Competing interests: We all receive funding from the Australian Research Council for research on the TPPA, health and nutrition. Deborah Gleeson has received funding from various national and international non-government organisations to attend speaking engagements related to trade agreements and health, including the TPPA. She has represented the Public Health Association of Australia on matters related to the TPPA. The views expressed in this article are our own and not those of any organisation we are affiliated with.

Provenance: Commissioned; not externally peer reviewed. 
1 Baldwin R. 21st century regionalism: filling the gap between 21st century trade and 20th century trade rules. Staff Working Paper ERSD-2011-08. Geneva: World Trade Organization, 2011.

2 Fergusson IF, Cooper WH, Jurenas R, Williams BR. The TransPacific Partnership negotiations and issues for Congress. Washington, DC: Congressional Research Service, 2013.

3 Gleeson D, Friel S. Emerging threats to public health from regional trade agreements. Lancet 2013; 381: 1507-1509.

4 Gleeson DH, Tienhaara KS, Faunce TA. Challenges to Australia's national health policy from trade and investment agreements. Med J Aust 2012; 196: 354-356.

5 Department of Foreign Affairs and Trade. Trans-Pacific Partnership Agreement: Canberra: Australian Government, 2014. http://dfat.gov.au/trade/agreements/tpp/Pages/transpacific-partnership-agreement-tpp.aspx (accessed Feb 2015).

6 Rollins A. Fears cloud trade pact despite govt assurances. Australian Medicine 2014; 11 Nov. https://ama.com.au/ausmed/ fears-cloud-trade-pact-despite-govt-assurances (accessed Jan 2015).
7 Lopert R, Gleeson D. The high price of "free" trade: U.S. trade agreements and access to medicines. J Law Med Ethics 2013; 41: 199-223.

8 Monasterio E, Gleeson D. The Trans Pacific Partnership Agreement: exacerbation of inequality for patients with serious mental illness. Aust N Z J Psychiatry 2014; 48: 1077-1080.

9 Thow AM, Snowdon W, Labonté R, et al. Will the next generation of preferential trade and investment agreements undermine prevention of noncommunicable diseases? A prospective policy analysis of the Trans Pacific Partnership Agreement. Health Policy 2015; 119: 88-96.

10 Schewel M. Under the radar, TPP parties wrestle over carveouts on services, SOEs. Inside U.S. Trade 2014; 32 (30).

1 Public Health Association of Australia. Protecting the health of Australians in the Trans Pacific Partnership Agreement negotiations [media release]. 17 Feb 2014. http://www. phaa.net.au/documents/140217\%20TPPA\%20Health\%20 Impact\%20Media\%20Release.pdf (accessed Jan 2015). 